\title{
Admissibility in International Arbitration and The Consequence of Inadmissible Cases
}

\author{
Buntario Tigris Darmawa Ng \\ \{notarisbuntario@gmail.com\} \\ Jalan Batu Ceper 19 D E F, Jakarta, 10120
}

\begin{abstract}
Admissibility in international arbitration is a preliminary objection which can be brought upon by a party in a response for an international claim. There are two types of objection brought over in admissibility cases, the first is jurisdictional objection and the second is competence objection. To this date, there is no consensus between multiple investment arbitration rules and court rulings on the definition of admissibility. Investment arbitral courts are given wide discretion on deciding matters regarding an admissibility of a case in front of the tribunal. Admissibility plays an important role in investment arbitration proceedings as one of the basis of claim dismissal and it should be clearly separated from jurisdictional matter. This differentiation is related to the different outcome for cases which are rejected based on admissibility or jurisdictional issue. Claims which are dismissed because of jurisdictional issue cannot again be submitted in front of tribunal, however cases with admissibility issue may be resubmitted in front of the tribunal if the requirements have been fully met. A fine distinction between jurisdiction and is required to solve the inconsistencies of this matter. This distinction has a huge implication on a claim and is also linked directly to whether a claim is able to be resubmitted and matters concerning the annulment of investment arbitral awards.
\end{abstract}

Keywords: investment; arbitration; admissibility; jurisdiction; objection; claim

\section{Introduction}

Admissibility in the context of international arbitration is a type of preliminary objection which can be brought by a party to response for an international claim. The type of objection brought over in admissibility cases usually revolves around jurisdictional objection and objection regarding competence. The term jurisdiction in international arbitration is often synonymous with both competence and admissibility and sometimes are used to cover both [1].

However, it should be noted that jurisdiction is merely an existence of adjudicative power and the exercise of such power is what we should call admissibility [1] Admissibility could be defined as whether a tribunal can exercise that adjudicative power to claims submitted into itself and are more closely related to the merits of a case. Furthermore, to separate this issue, it could be said that if the reason of outcome is that the claim cannot be brought to that forum, the issue is jurisdictional however if the reason is that the claim could not be heard at all at that forum, the issue is regarding the matter of admissibility [1].

However, to this date, there is no consensus regarding the term "admissibility" between various investment arbitration rules, such as the ICSID Arbitration Rules, UNCITRAL Rules or even in bilateral investment treaties. As the result of this lack of uniformity, investment arbitral courts are given a wide discretion on deciding matters regarding an admissibility of a 
case in front of the tribunal. This differs from international litigation which is very familiar with admissibility concept. Such example can be seen from Article 79 (1) of Rules of the Court of International Court of Justice (ICJ). On the context of non-investment tribunal rules, the term admissibility is defined in that article which read as follows:

"Any objection by the respondent to the jurisdiction of the Court or to the admissibility of the application, or other objection the decision upon which is requested before any further proceedings on the merits, shall be made in writing as soon as possible, and not later than three months after the delivery of the Memorial. Any such objection made by a party other than the respondent shall be filed within the time limit fixed for the delivery of that party's first pleading."

Various investment arbitration rules such as ICSID convention have defined the concept of jurisdiction in a strict sense. An example of jurisdiction claim in investment arbitration is nationality of the claimant. Furthermore, the term of admissibility has never been mentioned in ICSID convention nor its arbitration rules. This view is expanded in which according to leading commentary of ICSID convention, an ICSD tribunal must exercise its jurisdiction and decide any dispute that meets the jurisdictional requirement as per stated in the Article 25 of ICSD convention [1]. Failure in exercising this jurisdictional requirement may result in the annulment of arbitral award.

However, the application of admissibility on ICSID itself still inconsistent which is caused by the lack of written rules or guidelines on this matter. On the other side, some arbitration courts have decided that admissibility has its application in investment arbitration. This is reflected in which the court is permitted to refuse or reject a claim which has met the jurisdictional requirements. The view produced by these courts are that admissibility are based on the defects in a claim and jurisdiction is rooted on the authority of such court to decide a claim.

Based on the distinction between admissibility and jurisdiction objection above, it can be further expanded concluded that there is two different type of admissibility claim that is possible in investment arbitration court. First, if a claim jurisdiction requirement has been fully met and the respondent in this scenario challenges the validity of that claim to be the subject of exercise of that tribunal court. Another possibility is that the jurisdiction requirement in a case is not met and the claimant in this scenario argued about the unfulfilled requirement to avoid the dismissal of his claim. Generally, in a case which admissibility issues are in question, the burden of proof fall on the respondent's shoulder. Applicant is not required to prove admissibility during the application process and the respondent must prove inadmissibility to dislodge the application.

The distinction between jurisdiction and admissibility is important in international arbitration context. Although either jurisdictional challenge or admissibility challenge was aimed toward preventing the tribune from deciding on merit of the dispute [1]. This classification is important to determine several issues such as who will bear the burden of raising the objection, the procedural and substantive nature of an objection and which law is applicable. Another important thing to note is that on jurisdiction challenge the courts have final review on the matter however on admissibility challenge the courts should have no say on tribunal's decision. In accordance with New York Convention, state courts will refrain from conducting review of the merits of dispute when a party seeks the enforcement or annulment of arbitral award and as the result courts do not have the power to review tribunal's decision on admissibility issues [1]. Furthermore, to make a finding on admissibility issues, the tribunal should assert their jurisdiction. Classification of jurisdiction and admissibility 
issues have a massive effect on the parties of arbitration, the arbitral tribunal and the review process of such decision.

\section{Defining Admissibility in Investment Arbitration}

We have established in the previous section that currently there is a lack of general rule regarding admissibility in investment arbitration. On ICSID rules, the term admissibility is never mentioned and instead uses the term competence [1]. This makes the distinction between admissibility and jurisdiction become less clear on ICSID arbitration. ICSID relied on admissibility on cases in which they decline to exercise their jurisdiction and to held back from deciding any claims. It is usually applied that if the case is not considered as "ready" by the tribunal due to various issues such as lack of exhaustive local remedies or time limit.

As the result of this, we need to look at various investment arbitration cases to determine what is admissibility. It should be noted however that various tribunals have enforced their own interpretation and standard regarding this matter. For example, in case Waste Management Inc v. United Mexican States, admissibility as mentioned in dissent are interpreted as follows: "International decisions are replete with fine distinctions between jurisdiction and admissibility. To the present proceedings, it will suffice to observe that lack of jurisdiction refers to the jurisdiction of the Tribunal and inadmissibility refers to the admissibility of the case. Jurisdiction is the power of the tribunal to hear the case; admissibility is whether the case itself is defective - whether it is appropriate for the tribunal to hear it. If there is no title of jurisdiction, then the tribunal cannot act."

According to this line of thinking, the tribunal in assessing admissibility claim must first determine whether the claim has fulfilled the jurisdictional requirements needed to be brought in front of the tribunal. On the other hand, because there is no general guideline and consensus itself on which separates jurisdictional requirement and admissibility, this matter is not always clear and straightforward to determine. In the decision of Abaclat v. Argentina, the majority agreed that the matter of number of claimants falls under admissibility requirement instead of jurisdictional requirement. Abaclat claimed that Argentina has breached the terms set in the bilateral investment treaty by failing to ensure the security and protection of its investment and Argentina challenged the admissibility and jurisdiction claims brought by Abaclat. The majority decision stated that it is necessary to make a clear distinction between admissibility and jurisdiction as reflected in this following passage [1]:

"If there was only one Claimant, what would be the requirements for ICSID's jurisdiction over its claim? If the issue raised relates to such requirements, it is a matter of jurisdiction. If the issue raised relates to another aspect of the proceedings, which would not apply if there was just one Claimant, then it must be considered a matter of admissibility and not of jurisdiction."

Furthermore, the majority clearly distinguished the difference between admissibility and jurisdictional matter in these following lines:

a. While a lack of jurisdiction stricto sensu means that the claim cannot at all be brought in front of the body called upon, a lack of admissibility means that the claim was neither fit nor mature for judicial treatment.

b. Whereby a decision refusing a case based on a lack of arbitral jurisdiction is usually subject to review by another body, a decision refusing a case based on a lack of admissibility can usually not be subject to review by another body. 
c. Whereby a final refusal based on a lack of jurisdiction will prevent the parties from successfully re-submitting the same claim to the same body, a refusal based on admissibility will, in principle, not prevent the claimant from resubmitting its claim, provided it cures the previous flaw causing the inadmissibility.

We can conclude based on those lines above that the tribunal clearly defined the difference between inadmissibility and the lack of jurisdiction. In Abaclat case, the respondent argued that the number of claimants (which is never strictly regulated in ICSID convention rules) is a basis for inadmissibility. The tribunal in this claim held the opinion that the huge number of claimants (around 60.000 investors, which is normal considering the type of investment in this case) was a matter of implementation of ICSID proceedings rather than consent from respondent to ICSID arbitration thus making this problem of admissibility not a jurisdictional one.

This line of thought is debated within the tribunal itself because Professor Georges AbiSaab who wrote the dissent disagreed with this notion of thinking. He found that the majority's view of jurisdiction in this matter is extremely narrow. He further explained that the number of claimants in this case is tightly related to the concept of consent to arbitrate hence it should be a matter of jurisdiction. He also explained in detail the difference between two meaning of jurisdiction which should be met in any case brought forth in front of international tribunals. The first is the legal power of a tribunal and the second one is the scope in which the tribunal can exercise its legal power. He argued that the tribunal often only think the matter of jurisdiction in the second meaning while ignoring the first matter, which is whether if the tribunal has the legal power over a claim at all [1].

In this claim, he argued that the jurisdiction requirement is not met unless both objective requirements contained in the Article 25 of ICSID convention and consent of each disputing parties has been fulfilled [1]. This debate stemmed from the lack of clear rule regarding what constitutes jurisdictional matter and admissibility in investment arbitration tribunals. In some cases, the tribunal decide the matter of admissibility in merits rather than jurisdiction. On the other hand, because the tribunal is given a wide discretion to determine what admissibility covers, some cases also found that the matter of jurisdiction and admissibility is decided at the same time.

It could be said that the matter of admissibility on a claim is located somewhere between jurisdiction and merit. Although in international law admissibility could be found clearly in Article 79 of ICJ, the practical application of this article left a lot to be desired. Some tribunals and experts have taken the approach that admissibility and jurisdiction have no real difference in practical situation. The writer disagrees with the notion that there is no difference between jurisdiction and admissibility. It could be understood that the line and boundaries between admissibility and jurisdiction are a "twilight zone" [1]. On Methanex vs. United States, the tribunal concurred that it is very important to determine the difference between admissibility and jurisdiction however hard and uncertain the line between both might be. Zachary Douglas proposed that admissibility, which in his opinion is neither jurisdiction nor merit, could be defined as follows [1]:

"The grounds of inadmissibility at base represent certain legal defects in a claim that are independent of, and yet often closely connected to, to the substantive grounds upon which a claim or counterclaim is to be adjudicated on the merits. Admissibility deals with the suitability of the claim for adjudication on the merits".

To differentiate what constitutes as jurisdiction and what constitutes as admissibility, we should first determine what exactly is admissibility. It is important to distinguish what constitutes both if in a claim it has been founded that all the jurisdictional requirements are 
met. Admissibility may contain various issues related to the claim such as whether the plaintiff has the right to bring forth a particular claim or seek a relief from a claim, matters related to arbitral and judicial function, issue whether the claim is similar from another, the necessary involvement of a third party and res judicata among others.

An example regarding the difference between admissibility and jurisdiction can be seen in this following scenario. The assessment regarding jurisdiction can be determined at the date of arbitration request however the assessment regarding admissibility may take account from the latter facts that are revealed. Another example is that court may exercise its discretion on the claim that has fulfilled all its jurisdictional requirement and it may be inadmissible [1]. Jurisdictional matters often involve the tribunal and the parties themselves and admissibility is reserved to matters related to the claim

\section{Consequence of Admissibility in Investment Arbitration}

Understanding what the difference between admissibility and jurisdiction is critical for the disputing parties and the consequence for the claim itself. A claim has only one chance to meet a jurisdictional requirement which is commonly done at the time when arbitration process is started. However, courts may exercise greater flexibility in a case which they temporarily do not have a legal power by suspending it on a basis of admissibility. As the suspension on basis of admissibility is a temporary one, a claimant is permitted to complete the missing requirements and submit the claim once it has been fulfilled. The option to complete a requirement after the submission of an arbitration claim is not available for claims that do not meet the jurisdictional requirement. The claimants have only one chance to fulfil the jurisdictional requirement which usually is examined on the date of submission.

Another example because it is important to distinguish between admissibility and jurisdiction is because generally the objection regarding admissibility could be waived by the tribunals. For example, the matter regarding exhaustion of local remedies is generally considered as an admissibility problem rather than jurisdictional one. In RosInvest v. Russian Federation, the tribunal stated that the fact that local remedies can be waived demonstrates that the issue is not a jurisdictional matter. However, this is not always accurate as the host State is fully capable of waiving any condition for its consent and the possibility of a requirement to be waived does not diminish that condition from its jurisdictional issue. To further expand this point, in case Waste Management vs Mexico, the defect in the waiver requirement of the treaty is considered by the tribunal as a jurisdictional issue and once this issue is rectified by the investors, they are permitted to submit the claim once again in front of investment arbitration tribunals. As confirmed by the tribunal in Abaclat case, it is not only appropriate but also necessary to distinguish issues related to ICSID jurisdiction and admissibility issue.

In some bifurcated cases which the matter of jurisdiction and liability are totally separate, the tribunals which distinguish admissibility and jurisdiction usually only deal with the admissibility issue in merit phase. However, in some cases, the issue of admissibility and jurisdiction is combined into a single decision on both admissibility and jurisdiction. The Abaclat case shows this perfectly when the tribunals decided whether the matter of mass claim should fall under the scope of admissibility rather than a jurisdictional one. Issues regarding admissibility and jurisdiction is decided in the same time because the tribunals are given broad discretion on determining which are which. The decision to bifurcate a claim or not is conducted by the tribunal on a case per case basis given the wide discretion granted and the 
lack of guidelines on this matter. As we can see on Chevron vs. Ecuador, the tribunal explained its stance related to this distinction in the following manner:

"The respondent's objections to the admissibility of the claimants' claims, where not amounting to or overlapping with its jurisdictional objections, should be treated under Articles 15 and 21 of the UNCITRAL Arbitration Rules as issues relating to the merits phase of these arbitration proceedings. The UNCITRAL Rules do not contain any provision equivalent to ICSID Arbitration Rule 41(5). An objection to the admissibility of a claim does not, of course, impugn the jurisdiction of a tribunal over the disputing parties and their dispute; to the contrary, it necessarily assumes the existence of such jurisdiction; and it only objects to the tribunal's exercise of such jurisdiction in deciding the merits of a claim beyond a preliminary objection. Under the UNCITRAL Arbitration Rules, that is an exercise belonging to the merits phase of the arbitration, to be decided by one or more awards on the merits."

Further importance to distinguish between admissibility and jurisdiction could be linked directly on which tribunal and by what way the awards can be reviewed. Challenges done by parties that seek to annul of an arbitral award before ICSID committees may only bring forth the matter concerning the existence of an adjudicative power (jurisdiction) rather than exercise of such power (admissibility). Generally, the jurisdiction objection of tribunal can be reviewed either by a non ICSID national court or by ICSID annulment committee however decision on admissibility usually cannot be reviewed. It should be noted that ICSID awards are only reviewable under specific regulations under the ICSID convention (Article 52 (1) ICSID). Article 52 (1) described five grounds of annulment of ICSID arbitral awards which are as follows:

a. The Tribunal was not properly constituted.

b. The Tribunal has manifestly exceeded its powers.

c. There was corruption on the part of a member of the Tribunal.

d. There has been a serious departure from a fundamental rule of procedure.

e. The award has failed to state the reasons on which it is based.

From Article 52 (1) above, it could be determined that the wrongful application of jurisdiction falls under point $\mathrm{b}$ and point $\mathrm{e}$ however it is unclear in which way and inadmissibility could affect the annulment of an ICSID arbitral award. As the result of those annulment ground stated above, it is very hard to find a scenario in which an ICSID annulment committee annul the award based on erroneous application of admissibility. On the other hand, one could argue that the misinterpretation of a tribunal on jurisdictional matters into merely an admissibility one could be classified as manifestation of excessive powers hence become a ground of award annulment. If we agree on that approach, ad hoc committee would be a place where the parties appeal on matter of inadmissibility. This brings further debate in which Zachary Douglas perfectly summed up. We have previously established that Douglas believe that admissibility is located somewhere between jurisdiction and merits. The tribunal on ICS vs. Argentina stated in their decision as follows:

"Admissibility falls somewhere in between these extremes. It is not an area where a tribunal enjoys discretion to simply disregard the requirement that has not been fulfilled, but rather one in which the tribunal enjoys some discretion as to how deal with its non-fulfilment, such as by staying instead of terminating the proceedings".

Douglas firmly believe that the matter of admissibility should not be decided by ad-hoc committee since the matter of admissibility is more closely related to merits rather than jurisdictional issue. On the other point of view, in case Abaclat, the tribunal opined that admissibility must be established first prior to entering merit. Abaclat further stated that a case that lacks jurisdiction is reviewable by another body however a case that lacks admissibility 
usually are not eligible to be reviewed by another body. ICSID stance regarding "excess of power" and its decision to not refuse exercising their power on grounds of admissibility can be seen again in case Mobil Oil vs Venezuela which the committee held the opinion as follows:

"The Committee also accepts that there is weight in the Mobil Parties' contention that questions of admissibility may require to be approached in a different way from questions of jurisdiction for the purposes of the annulment scheme laid down in Article 52 of the ICSID Convention. It is plain on the face of it that the reference in Article 52(1)(b) to a tribunal having 'manifestly exceeded its powers' fits most naturally into the context of jurisdiction, in the sense that it covers the case where a tribunal exercises a judicial power which on a proper analysis had not been conferred on it (or vice versa declines to exercise a jurisdiction which it did possess). It follows that it is less easy to apply the criterion laid down in Article 52(1)(b) and when it comes to deciding whether the excess was 'manifest' - when what the tribunal is doing is to make a discretionary assessment of whether, assuming the existence of its judicial power in principle, it is proper in the particular circumstances for that power to be exercised ... The Committee does not, however, have to decide any of these questions."

We have established previously that admissibility only means a temporary suspension on a claim, we can hereby conclude that inadmissibility in a claim does not mean res judicata. Based on the definition above, it can be said that the court which decline to examine a claim based on admissibility have exercised their jurisdictional power in that action. The court only decline the claim based on procedural condition such as waiting period and determination. If this requirement is going to be fulfilled by the claimant, it could be said that the claim is admissible hence does not become res judicata. In case Murphy vs. Ecuador, the claimant (Murphy) is permitted to initiate a second arbitration after they have fulfilled the requirement of waiting period.

\section{Admissibility in non-investment arbitration cases}

To this date, there are only a few cases concerning admissibility in non-investment arbitration courts. There is also a lack of unified and specific rules for each tribunal to follow on deciding admissibility matters. However, we can use our knowledge from various investment and commercial arbitration cases to determine admissibility in non-investment arbitration setting. This chapter will explain some example of admissibility cases in commercial arbitration and what can we learn from that cases.

The first case is J.N.A.H vs Marriott which was brought in front of the French Court of Cassation (Cour de Cassation). J.N.A.H and Marriott had entered into a hotel operating agreement which contained International Commercial Chamber (ICC) clause. A dispute arose between them and two decisions were judged under ICC rules. In the first arbitration (JNAH I), the tribunal found that Marriott had breached various terms of agreements and in the second arbitration (JNAH II), the tribunal ordered Marriott to compensate J.N.A.H for the breaches conducted by Marriott. However, during this decision, the tribunal had refused jurisdiction over the Parties' claim arising from the termination.

In the middle of second proceeding, the Fakhri family who owned the majority of J.N.A.H shares decided to sell their stake in the company to a third party. It was agreed between both parties that the award in the second proceeding will be retained by the family. Furthermore, the family had also been given full authority and control over the Marriott case by the new shareholders in form of irrevocable power of attorney which was held by a 
representative from Fakhri family. Using the power of attorney, they soon filed a third arbitration proceeding (JNAH III) against Marriott to request compensation for damages which arise from termination. The tribunal ruled in Marriot favour because it does not have jurisdiction over the claim. The tribunal concluded that the granted power of attorney is only limited to JNAH I and JNAH II cases and does not cover for future claims.

Unsatisfied with the result, JNAH decided to file against the jurisdiction claim on Paris Court of Appeals. The court decided to annul the award on jurisdiction and concluded that the arbitral tribunal's view on power of attorney is extremely narrow. The power of attorney in this case should cover all disputes between J.N.A.H and Marriott, not just for the first and second proceedings. To this decision, Marriott decided to appeal to French Court of Cassation. The Court of Cassation decided to overturn Paris Court of Appeals' decision on the basis that they had mistakenly rule on their jurisdiction over J.N.A.H claim. The Court of Appeals' decision should be ruled based on admissibility.

By assessing the scope of power of attorney, the court in fact had ruled on admissibility on this third proceeding. Court of Cassation determined that the Court of Appeals' application of Article 1520-1 CPC (which only applicable on jurisdiction cases) was incorrect and overturned. Further appeal was done by J.N.A.H to Versailles Court of Appeal which rejected the appeal for annulment and sentenced J.N.A.H to pay 50.000 euros according to Article 700 of CPC. In this decision, we could see that the French court draws a clear line between admissibility and jurisdiction matters. Jurisdiction of a tribunal should be determined by the arbitration agreement between the Parties. However, because this case concerns J.N.A.H's power or lack thereof, it should be determined as an admissibility issue.

Another case we should look at is BG vs Argentina which was decided by the U.S. Supreme Court on 2014. The dispute arose from emergency actions taken by Argentine government during their economy crisis in 2001. BG Group was a company with huge investment in Argentine gas distribution company and as the result was affected by government actions during the crisis. They initiated arbitration against Argentina in accordance with Article 8 of UK-Argentina BIT. The relevant provisions of the BIT are Articles 8(1) and 8(2) of the dispute settlement clauses, which are:

1. Disputes regarding an investment which arise within the terms of this Agreement between an investor of one Contracting Party and the other Contracting Party, which have not been amicably settled shall be submitted, at the request of one of the Parties to the dispute, to the decision of the competent tribunal of the Contracting Party in whose territory the investment was made.

2. The disputes shall be submitted to international arbitration in the following cases:

a. If one of the Parties so requests, in any of the following circumstances:

- where, after a period of eighteen months has elapsed from the moment when the dispute was submitted to the competent tribunal of the Contracting Party in whose territory the investment was made, the said tribunal has not given its final decision;

- where the final decision of the tribunal has been made but the Parties are still in dispute;

b. Where the Contracting Party and the investor of the other Contracting Party have so agreed.

BG started the arbitration without first attempting to bring the case in front of Argentina courts. The tribunal held that BG action was permissible because according to their finding, Argentina had prevented various actions to be taken in their domestic court. BG won on the 
proceeding and the award was confirmed by U.S District Court of District of Columbia. On the appeal, the DC circuit reversed the decision and stated that the tribunal lack jurisdiction on this case because BG was supposed to go through Argentina domestic court first prior commencing any arbitration proceedings. Another point made by DC Circuit was that BG needed to wait at least 18 months to commence arbitration as per Article 8 UK-ARG BIT.

Upon appeal, the U.S. Supreme Court decided to reverse DC Circuit's ruling. The majority, summed by Justice Breyer, concluded that litigation pre-condition was a matter of procedural arbitrability which determines when a duty to arbitrate arises not whether it exist. The main issue for this case was whether the Supreme Court should defer the arbitrators' decision on litigation pre-condition or decide a new ruling based on the facts. If the matter of litigation was substantive and dealt with the arbitration agreement, a new ruling should be issued by the Supreme Court. On the other hand, if the matter was a procedural one, U.S. Supreme Court should defer the ruling to the arbitrators and upheld DC Circuit's ruling. Another important question to answer was who would decide the matter in such case, whether the courts or the arbitrators.

In Howsam vs Dean Witter Reynolds, the answer to this predicament was clear. The ruling on that case was to differentiate between jurisdiction (substantive arbitrability) and admissibility (procedural arbitrability). According to US Law, the courts can issue new ruling on jurisdiction issues however they need to defer to arbitrators' decision on admissibility issues. Argentina on this case is trying to portray that domestic litigation is a condition of its consent on arbitration hence shifting the matter as a jurisdiction issue. This is to ensure that the U.S. Supreme Court declare a new ruling on the issue instead of deferring to the arbitrators' decision. However, the U.S. Supreme Court held that conditions precedent to an obligation to arbitrate are "procedural" and therefore for the arbitrators to decide.

These are few examples of cases in which could be considered as "twilight zone". There are various instances which might be difficult to determine whether an issue falls under jurisdiction or admissibility. Unlike obvious things such as time limit (example of admissibility) and validity of an agreement (example of jurisdiction), issues that arise in cases like Marriott and BG are hard to classify under one umbrella. In BG, it could be argued that because Article 8 BIT enable the investor to set forth arbitration proceeding after a certain period, Argentina's objection does not mean that an arbitral forum is unable to decide the dispute which becomes an admissibility issue.

On the other side, because the precondition in the agreement is recourse in Argentinian courts, it could be argued that Argentina was challenging the competence of the forum. If so, this falls under jurisdiction issue. However, in my opinion, BG was an admissibility issue which was reflected in the litigation pre-condition. The same goes with Marriott, in which the power of attorney issue should be classified as admissibility.

From the cases above, they do not offer a clear guidance to navigate twilight zone cases although they reached the right outcome. They still left unanswered questions and minimal guideline on how future cases like those above will be determined. However, we could use our knowledge from investment arbitration cases which dealt with similar issues and apply them in these twilight zone cases. For example, using ICSID framework, BG case would be a far more streamlined and effective procedure.

Using ICSID convention rules, application for annulment might only be made based on Article 52 (1) of ICSID convention. An ad hoc committee will be appointed and render the decision on annulment. If the annulment is not granted, the award will be automatically bind both parties based on Article 53 (1) and Article 54(1) of ICSID convention. ICSID framework eliminates the involvement of national courts on determining the validity of awards. 
This process is totally different for non-ICSID framework as reflected in both BG and Marriott case. Both losing parties in those cases challenged the validity of arbitration award in national courts. Difficult cases might go through a nation's whole court system before decision being rendered which ultimately could take years from starting a proceeding to receiving its final decision. Furthermore, this problem is exacerbated by the lack of knowledge of national courts judges on international investment disputes. National courts judges are also affected by their own country law and as the result could render the decision based on their view instead of being impartial. In ICSID cases, judges are replaced by ad hoc Committee. Ad hoc Committee members are appointed from a panel of ICSID arbitrators, hence would be more likely to be accustomed on dealing with international investment disputes.

Another parallel on guidance regarding admissibility and jurisdiction can be seen in International Court of Justice (ICJ) Article 79 which was recently amended in 2019. Article 79 which regulate issues regarding preliminary objections received most changes. It was expanded into multiple parts (Article 79 bis and Article 79ter) and a new guideline was introduced. Article 79bis and Article 79ter read as follows:

\section{Article 79bis}

1. When the Court has not taken any decision under Article 79, an objection by the respondent to the jurisdiction of the Court or to the admissibility of the application, or other objection the decision upon which is requested before any further proceedings on the merits, shall be made in writing as soon as possible, and not later than three months after the delivery of the Memorial. Any such objection made by a party other than the respondent shall be filed within the time-limit fixed for the delivery of that party's first pleading.

2. The preliminary objection shall set out the facts and the law on which the objection is based, the submissions and a list of the documents in support; it shall include any evidence on which the party relies. Copies of the supporting documents shall be attached.

3. Upon receipt by the Registry of a preliminary objection, the proceedings on the merits shall be suspended and the Court, or the President if the Court is not sitting, shall fix the time-limit for the presentation by the other party of a written statement of its observations and submissions, which shall include any evidence on which the party relies. Copies of the supporting documents shall be attached.

4. The Court shall give effect to any agreement between the parties that an objection submitted under paragraph 1 be heard and determined within the framework of the merits.

\section{Article 79ter}

1. Pleadings with respect to preliminary questions, or objections filed pursuant to Article 79, paragraph 2, or Article 79bis, paragraphs 1 and 3, shall be confined to those matters that are relevant to the preliminary questions or objections.

2. Unless otherwise decided by the Court, the further proceedings shall be oral.

3. The Court, whenever necessary, may request the parties to argue all questions of law and fact, and to adduce all evidence, which bear on the preliminary questions or objections.

4. After hearing the parties, the Court shall decide upon a preliminary question or uphold or reject a preliminary objection. The Court may however declare that, in the circumstances of the case, a question or objection does not possess an exclusively preliminary character.

5. The Court shall give its decision in the form of a judgment. If the judgment does not dispose of the case, the Court shall fix time-limits for the further proceedings. 
In adding Article 79-part bis and ter, the court is given a main role in deciding whether the matter of jurisdiction and admissibility should be judged separately. Furthermore, Article 79 and its new additions also draw a clear line between the difference of preliminary questions and preliminary objections. According to the amended rule, question is those raised by court and objection are those raised by the party. However, since the rule is pretty recent, it is not clear yet what impact these new regulations are going to bring in regard to preliminary objections. Overall, ICJ has done a good job in noticing that the previous rule lacks clarity regarding this issue however it remains to be seen if these new regulations will bring a positive effect on the procedure and clarify the issue that still exist between jurisdiction and admissibility.

\section{Conclusion}

Concept of admissibility in international law is nothing new, however its application and definition in investment arbitration has not been fully clear. Admissibility plays an important role in investment arbitration proceedings as one of the basis of claim dismissal. As for today, the lack of clear rule regarding admissibility in investment arbitration provide the tribunals wide discretion this matter and what differentiate it between jurisdictions. To answer this question, it could be said that jurisdiction focuses on the parties and the tribunal itself where admissibility focuses on the claim itself.

Generally, a lack of jurisdiction means that the tribunal does not have the power to decide a case permanently and admissibility means that currently the tribunal may not have the power to exercise until the remedies on that matter has been found. The example brought forth in this journal is regarding the exhaustion of local remedies. The question of admissibility is whether the claim is temporarily defective in front of the tribunal. Admissibility function itself is clear, however what constitutes as admissibility and the line between admissibility and jurisdiction remain unclear. It is also unclear based on the available rule right now that a failure to meet procedural requirement falls into a jurisdictional issue or simply make the claim inadmissible.

Furthermore, we could conclude that there are consequences on which claim was ruled out because of jurisdictional issue or admissibility issue. Objection to jurisdiction means that the tribunal has no discretion because of strict and clear rule and as the result the claim shall be dismissed. The claim which is dismissed because of jurisdictional issue cannot again be submitted in front of tribunal. This is different from admissibility issue which the tribunals are given a freedom and discretion to determine which constitutes as admissibility. Inadmissibility is related to claim and as the result is not usually constituted clearly in investment arbitration rules.

As year follows, a clear distinction between jurisdiction and admissibility and a more specific and clearer rule regarding admissibility is required to solve the inconsistencies of this matter as viewed by the tribunals. This distinction has a huge implication on a claim and is also linked directly to whether a claim can be resubmitted and matters concerning the annulment of investment arbitral awards. The lack of clear guideline means that until this date there is still debate on the concept of jurisdiction and admissibility itself. We hope that tribunals and international law scholars both work together to clarify this issue to face the increasing amount of jurisdiction and admissibility issue in the future. 
Paulsson on his paper posits two-pronged test to determine which issues should be classified into jurisdiction and admissibility. The first test is if the reason for decision would be that the claim cannot be brought into the forum, the issue is a jurisdictional one and subject to further recourse. The second test is that if the reason for decision is that the claim should not be heard at all, the decision is final and concerns admissibility. The aim on this axiom is to clarify the blurred lines on jurisdiction and admissibility. This might be a good start to know how to differentiate between jurisdiction and admissibility, however until a clear and unified guideline are adopted, there are still going to be a lot of debate and confusion even between experts themselves on deciding this issue.

There is also a lack of clarity on how to deal with cases which are deemed inadmissible. In theory, cases which are deemed inadmissible can be brought again in front of the tribunal after all those requirements are met. Inadmissible cases are not supposed to be determined by courts, rather they should be dealt by the tribunal itself either via a Committee or some other way. However, to this date, the exact mechanism is unclear, and it is in their best interest to create a guideline on this issue

\section{References}

[1] Christoph Schreuer \& Loretta Malintoppi, The ICSID Convention: a commentary (2009).

[2] Zachary Douglas, The International Law of Investment Claims (2012), pp. 134-150

[3] Jan, Paulsson, Jurisdiction and Admissibility (November 11, 2010). GLOBAL REFLECTIONS ON INTERNATIONAL LAW, COMMERCE AND DISPUTE RESOLUTION, p. 601, ICC Publishing, 2005; University of Miami Legal Studies Research Paper No. 2010-30.

[4] Nikita V. Nota, International Arbitration: Some Reflections on Jurisdiction and Admissibility, 2 Ukranian J. Bus. L. 32 (2010).

[5] Julian M. Lew, Loukas A. Mistelis et al., Comparative International Commercial Arbitration 336 (Kluwer L. Intl. 2003)

[6] Article 41 Convention on the Settlement of Investment Disputes between States and Nationals of Other States, 18 March 1965, 575 U.N.T.S. 159

[7] Abaclat v. Argentine Republic, ICSID Case No. ARB/0715, Decision on Jurisdiction and Admissibility (Aug. 4, 2011),

[8] CSID Arbitration Rules, R.25

[9] SGS Société Générale de Surveillance S.A. v. Philippines, ICSID Case No. ARB/02/6, Decision of the Tribunal on Objections to Jurisdiction, 29 January 2004, 175-176.

[10] Venezuela Holdings BV et al v Bolivarian Republic of Venezuela, ICSID Case no ARB/07/27, Decision on Annulment, 9 March 2017, para 110-111.

[11] Murphy Exploration and Production Company International v. Ecuador, ICSID Case No. ARB/08/4, Award on Jurisdiction, 15 December 2010; Murphy Exploration \& Production Company - International v. Ecuador, PCA (pending)

[12] Republic of Argentina v BG Group PLC, 572 US (2014).

[13] Howsam v Dean Witter Reynolds, Inc 537 US 79 (2002). 